AP: Ontine Journat in Public Archaeology Special Volume $3-2018$ p. 25-54

\title{
Decisions and Adaptations on the Frontier: The Russian Cemetery at Fort Ross, Northern California
}

Lynne GOLDSTEIN

Michigan State University

Received: 09/09/2017 - Accepted: 26/06/2018

\begin{abstract}
This study focuses on stakeholders and changing perspectives on a heritage site. The case study is an historic cemetery within a public state park that was the location of a Russian colony in northern California: Fort Ross State Historic Park. From 19901992, I excavated the cemetery at the Russian Colony Ross, which was in use from 1812-1841, and which included Russians, Native Alaskans, Native Americans, and combinations thereof. A total of 135 burials were excavated and reburied. Although the Russian Orthodox Church has clear requirements for funeral and burial, the specific location and extent of the cemetery were unknown. Examining the site from the perspective of different stakeholders and their agendas, this article explores the changing nature of a mortuary heritage site, as well as how different groups interpret and use the same site, how communities reacted to the excavation project, and how the project continues to have an impact on communities. Various stakeholders have used the cemetery in different ways to memorialize their own pasts and make claims in the present.
\end{abstract}

\section{Keywords}

California, cemetery, mortuary excavations, public interpretation, Russians 


\section{Introduction}

David Lowenthal is noted for his famous critique of heritage: The Past Is a Foreign Country (1985). In 2015, he revisited and revised that classic volume, noting that the past is now even more bitterly contested and remade. His 2015 book places more emphasis on the notion of memory and its importance, noting that: 'The remembered past is malleable and flexible; what seems to have happened undergoes continual change' (Lowenthal 2015: 320). Likewise, in her now classic book on heritage studies, Uses of Heritage, Smith (2006) suggests that we should focus on heritage as a process, in order to better understand the social phenomena of 'heritage'. She identifies themes to examine heritage from this perspective: identity, intangibility, memory and remembering, performance, place, and dissonance. Relevant to the discussion here is that each of Smith's themes is not inherent in an object or thing, but is instead part of 'an active process of continual creation and recreation ... [that is] continually remade and negotiated' (Smith 2006: 301). Skrede and Hølleland (2018) reexamine Smith's 2006 work carefully, and although there are aspects they find confusing, they find value in the general approach and methodology. Similarly, Harrison (2013) finds heritage to be ubiquitous, and also notes that heritage is not a thing, but 'refers to a set of attitudes to, and relationships with, the past' (2013: 14).

The current research on heritage and heritage studies share some commonalities: heritage is not a thing or one thing, but is rather a process or set of relationships with the past. There seems to be general agreement that Smith's themes (2006) of identity, intangibility, memory and remembering, performance, place, and dissonance are key components of heritage, but how, where, and when they operate can be debated. While the past is integral to our being, and the whole past - ugly or not - is our legacy (Lowenthal 2015: 609-610), that legacy is not set in stone, but changes over time.

This article focuses on a historic, frontier cemetery, not describing or analyzing the site per se (see Osborn 1997 and Goldstein and Brinkmann 2006 for a discussion of the cemetery and its excavation), but instead looking at how perceptions of the cemetery have shifted over time. This involves considering how communities reacted to 
the excavation project, and how the project had, and continues to have, an impact on communities. In other words, I consider the cemetery to be a heritage site.

Fort Ross is (and was) an isolated location along the northern California coast (Figures 1 and 2). Today, it is a California State Park. During its existence as a fort from 1812-1841, it was a place with a multi-ethnic population (cf. Lightfoot 2005; Lightfoot et al. 1998). The cemetery is located across Fort Ross Creek from the fort, in view of the chapel. The Colony included European Russians, Yakuts from Siberia, creoles, native Alaskan Aleuts, native Alaskan Koniag Islanders, native Californian Pomo, native Californian Miwok, and occasional non-Russian Europeans and native Hawaiians (the Russians had another settlement on Kauai in Hawaii). From fifty to one hundred and twenty native Alaskans (including Aleuts, Koniag Islanders, and some Athabascan men from Cook Inlet) were stationed at Ross as specialized sea mammal hunters, with the apparent majority from Kodiak Island (Blomkvist 1972: 107; Federova 1973: 203; Knecht and Jordan 1985: 19). Approximately one hundred to two hundred Kashia Pomo, Southern Pomo, and coast Miwok people were recruited from nearby villages to work as agricultural laborers (Federova 1975: 12; Gibson 1976: 119). Inter-ethnic cohabitation and marriage was common (Federova 1975), although strict class and ethnic distinctions were maintained in more public spheres.

From 1990-1992, I directed excavations at the Fort Ross cemetery. Sannie Osborn, one of my Ph.D. students at the time and a Californian who had studied in Russia, proposed that her dissertation research focus on studying mortuary practices in the frontier setting of Fort Ross (Osborn 1997). A key question for Osborn's research and my own work was: what happens to prescribed customs of funeral behavior when certain members of a society are removed from the familiar surroundings of family, friends, and church, and relocated to a multi-ethnic frontier outpost such as the Russian colony at Fort Ross? Approaching the question required two major lines of research. First it demanded an extensive review of church and Russian-American Company records that might locate the names, ages, sex, causes of death, and other information for the individuals who may have been interred at the 


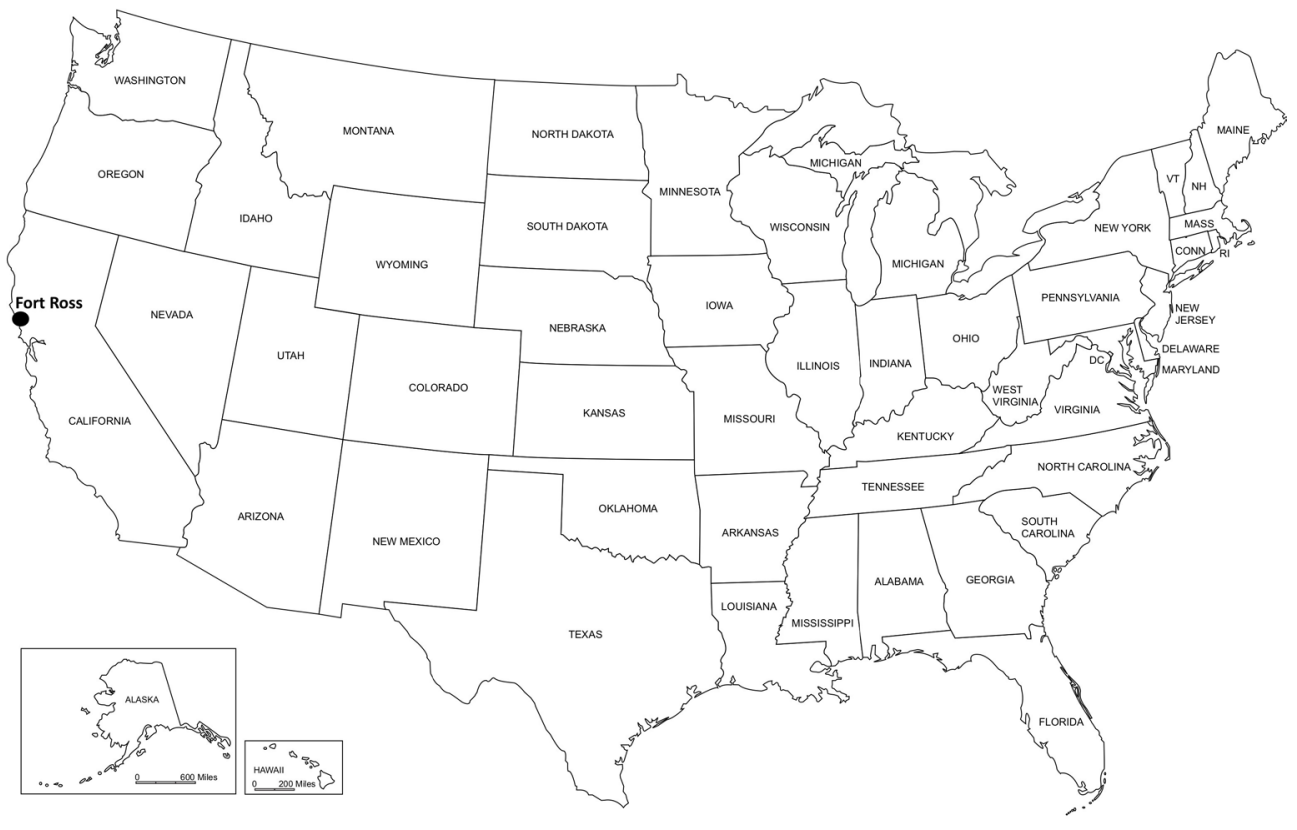

Figure 1: Location of the Fort Ross cemetery along the northern California coast.

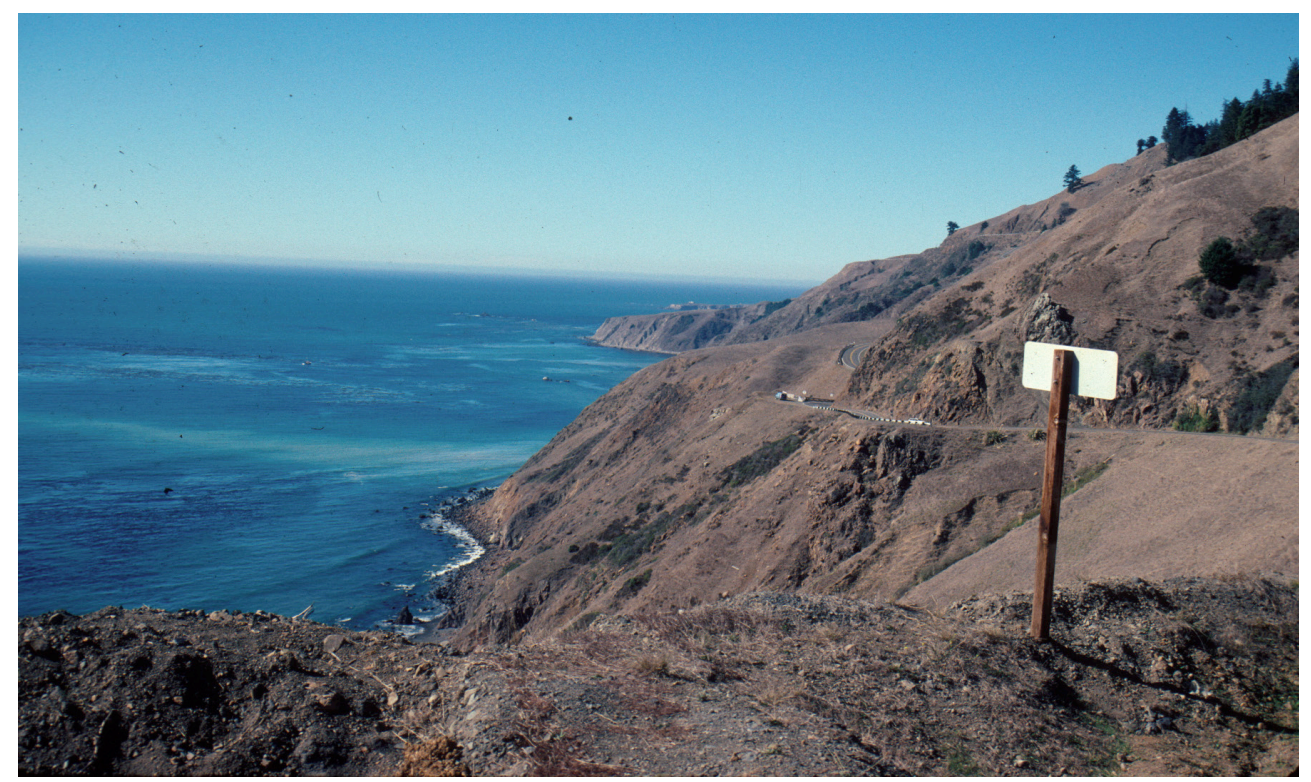

Figure 2: The rugged northern California coast (photo by L. Goldstein). 
cemetery. Second, the location and complete excavation of the Fort Ross cemetery was sought to allow determination of its nature and structure. Osborn's dissertation (1997) primarily focused on archival materials, and the first year of excavations, and my own research (Goldstein and Brinkmann 2006) was directed towards the complete cemetery excavation to explore spatial and chronological patterning in mortuary practice, including the possible effects of colonialism on native populations and the colonists. This article draws on this research by considering the use of the cemetery over time as an unfolding process of engaging with place, inspired by Lowenthal's and Smith's perspectives.

\section{Background}

Most people today see the northern California coast as a beautiful place for a vacation, hiking, or a drive (see Figure 2). However, it is also a dangerous place that includes the San Andreas Fault with earthquakes and mudslides, rockslides, and harsh conditions. Indeed, Fort Ross Creek, which divides the cemetery from the main fort, is part of the San Andreas Fault. This harsh environment has frequently been misunderstood. Notably, the Russians who colonized this landscape in the nineteenth century did not initially fully understand this location and its lack of suitability for farming (cf. Federova 1973; Goldstein and Brinkmann 2006). Even today, it is somewhat difficult to reach the site and the area is still only sparsely populated.

The Russian American Company officials who conceived of the idea of Fort Ross also thought that the colony might serve as a base for accumulating foodstuffs received via trade with the Spanish. The colony was ultimately not a success as an agricultural colony, in part because of the setting, and in part because the people who were initially sent to Ross were artisans and sea mammal hunters, not expert farmers. The Spanish interacted with Ross to some extent and some less perishable goods came via the Spanish to Ross and on to Alaska, but the Spanish largely ignored the colony once it saw that it posed no real threat. By 1836, the Company sent a trained agronomist to improve the agriculture of the Colony, but Ross was never a thriving agricultural enterprise (Gibson 1976). 
A variety of scholars have written about Colony Ross. Lightfoot and colleagues (1998) examined Ross from the standpoint of the different ethnic groups living there, demonstrating that their worldviews and structuring principles were indeed reproduced in daily practices at the site at different scales, while at the same time certain cultural transformations took place as people adapted to this new pluralistic setting. Farris (1992) illustrates these same points by outlining several stories recorded by linguist Robert Oswalt, and Lightfoot (2005) compares the Russian and Spanish experiences, particularly from the perspective of their influence on native groups.

The cemetery reflects this pluralistic setting. Initially, the Department of California Parks and Recreation estimated the number of possible burials in the neighborhood of fifty to seventyfive graves. This estimate was based primarily on descriptions of the cemetery made by Ernest Rufus, who leased Ross with a partner in 1845 (Hasse 1952: 25). Rufus indicates that there were never more than fifty graves in the cemetery, but we excavated a total of 135 graves. The disconnection between the number expected and the number recovered may simply be an issue of preservation; the wooden markers used to mark graves were not stable and they did disintegrate. In addition, Rufus and other early visitors may not have considered the possibility of a marker being gone, of a grave not having a marker, or of one marker indicating more than one grave. Rufus also may only have examined one portion of the cemetery, since the extent of the site is not indicated in his description. Rufus' was the first interpretation of the site.

\section{Stakeholders}

From the beginning of the Fort Ross cemetery research, it was clear that there were many different stakeholders with many contrasting perspectives, and it was considered critical in order to follow best archaeological practice to include them all in the planned work and decision-making process of the project. In the early 1990s, such inclusion was far from universal. However, in the previous twenty or more years, due to heightened sensitivities, California cemetery excavations were undertaken only when there 
was a direct threat from a construction project. In addition to the fact that there was no direct threat at this site, the multiethnic nature of Fort Ross required permission from groups with very different perspectives. The regional park archaeologist and I decided that our unusual request to excavate a non-threatened cemetery required active participation and approval from all possible stakeholders. Since the excavations took portions of three summers to complete, maintaining all of these permissions required extensive juggling, communication, and discussion. If any single group decided to withdraw their permission, the entire project would have been in jeopardy. Each stakeholder group had their own agenda(s), including specific information that they hoped the cemetery excavations would reveal.

As Clegg, et al (2013: 162) have much more recently noted: 'Those of us who undertake research on remains of past individuals need to acknowledge that there are different points of view...' They go on to point out that collaboration and providing an equal footing between groups represent the only way forward. This statement was true of the Fort Ross cemetery, and even though the excavations were undertaken some time ago when such sentiments were not ubiquitous in the archaeological community, there was an emphasis on collaboration, inclusion, and equal treatment.

A variety of scholars have focused on what is now called community archaeology or collaborative archaeology, and this is a positive direction for mortuary archaeology that has in large part been an outgrowth of repatriation and repatriation interactions (see Clegg, et al 2013; Fforde, et al 2002; and Williams and Giles 2016 for many examples). It is a direction that will be increasingly required of burial archaeologists in the future, and as Giles and Williams note:

...the last decade has been a profitable period of self-reflection in many different areas of archaeological practice: from how human remains are excavated, analysed, stored, how access is managed, and how the dead are displayed and to what ends.... (Giles and Williams 2016: 3) 
Both Redfern and Clegg (2013: 1) and Giles and Williams (2016: 3 ) recognize that a museum or other kind of display space is one of contextualization, interpretation, and engagement. Acknowledging many of the problems in creating such spaces, a number of the chapters in Williams and Giles (2016) 'explore the intersection between heritage and the archaeology of death and thus the contributions archaeologists make towards contemporary society's long-term perspective on mortality'(Giles and Williams 2016: 14). At Fort Ross, there is a small display museum, a reconstructed fort, and the cemetery is in a very visible part of the park, along Highway 1. Several meetings at Fort Ross were required to determine the list of stakeholders, and it required an additional eighteen months to receive all required written permissions.

The Fort Ross property is owned by the State of California, and operated by the California Department of Parks and Recreation. Conducting any archaeological work in the park requires permission from this department, and specifically the archaeologist in charge of the region. The regional park archaeologist was our main contact for all work throughout all phases of the project. He insured that we contacted all of the appropriate people, offices, and groups. Because the Fort Ross State Historic Park includes a museum, interpreters, and a reconstructed fort with buildings, permission and cooperation was needed from the individuals working in the park daily and doing the interpretation. The Fort Ross Interpretive Association (FRIA) is an independent organization that raises funds, oversees the bookshop and museum shop, and supports a variety of park activities. This group has an active board, including both scholars and local citizens. In more recent years, the Fort Ross Conservancy (FRC) has replaced FRIA, but for purposes of this discussion, the park support group was a critical stakeholder at the time of the fieldwork.

Excavating any burial in California also requires permission of the county coroner, and if Native American remains are potentially involved, the California Native American Heritage Commission must also grant permission. In general, the Heritage Commission insures that the appropriate tribes are contacted and involved. Once the commission grants permission, they turn over decision-making to the individual stakeholder tribe(s), unless there is a dispute. In terms of the county coroner, once he agreed that the cemetery 
was an historic one, he granted permission and we simply kept him informed of our progress.

At the time that we began the permissions process, two separate groups of the Russian Orthodox Church affirmed their relationship to the cemetery, and we worked with both groups extensively and intensively.

For those unaware of the structure of the Russian Orthodox Church (ROC), some clarification is warranted (cf. Wikipedia 2017). The ROC, the largest group of Russian Orthodox followers, claims jurisdiction over Orthodox Christians throughout the world. The ROC is not the same as the Orthodox Church of America (OCA), another Orthodox Church that traces its existence in North America to the time of the Russians in Alaska in the late 18th century, and thus relevant to Fort Ross. The OCA group adheres to the ROC liturgical tradition.

A third group is the Russian Orthodox Church Outside Russia (ROCOR) (Wikipedia). Russian communities outside thenCommunist Russia established this group in the 1920s; they refused to recognize the authority of the Moscow Patriarchate. As of 2007, ROCOR is a self-governing part of the Russian Orthodox Church. We did not directly interact with ROCOR. ROCOR was organized long after the time of the occupation of the Fort, and they left interactions with us up to the other two groups.

All branches of the Church were interested in the cemetery excavations because they wanted more detailed knowledge about the individuals in the cemetery, as well as the extent and layout of the cemetery. Further, the cemetery represents a visual, clear link between the Russians of the past and the Russians today. The Church groups also wanted it made physically clear that this area was consecrated ground; at the time excavations began, there was a simple interpretive sign noting the past cemetery and there were sheep grazing on the site. One of the Russian Orthodox groups came out to the cemetery area in the 1970s - without park permission - and put up a large wooden Russian Orthodox cross to demarcate the area as sacred. Once excavations were completed, a group of Russian Orthodox Boy Scouts made individual Russian Orthodox crosses for each burial, and the archaeologists, with the assistance of several priests, placed a cross in the proper location on each grave (Figures 3 and 8). 
Two native California tribes - the Kashia Pomo and Bodega Miwok - were identified as having historic relationships with the Russians at the site. The Bodega Miwok allowed the Kashia Pomo to take the lead in terms of California native input on the project for several reasons. First, when we requested permission in 1989-90, the Bodega Miwok were not well organized as a tribe, and did not have individuals available to serve as collaborators or monitors. Second, the majority of non-Alaska natives who interacted with the Russians at the fort were Kashia Pomo.

The Kodiak Area Native Association (KANA) provided permission for excavation on behalf of Alaska natives, since most of the Alaska natives present at Fort Ross were known from historical records to have come from Kodiak Island. After giving permission, KANA later decided to defer in ongoing decision-making to the Russian Orthodox priest in Alaska, and he provided comment and input on the excavations. The priest also visited the site several times. To be clear, it was not that the Alaska natives were uninterested in the excavations, but the distance from California and the fact that any native Alaskans at the fort would have converted to Russian Orthodox, meant that they were comfortable leaving dayto-day oversight to the Church, and specifically to this priest. We provided KANA with regular project updates. In the last few years, some additional Alaska native groups have expressed interest in the cemetery, but this was not the case in 1989-90. By August 1992 , everyone was reburied in their original graves, so the current interest by these groups has focused on cemetery interpretation. Based on the poor bone preservation at the site, we could not have determined the presence of specific individuals, and it is doubtful that we would ever have been able to distinguish between different Alaskan groups.

At the end of the permissions process, the groups we interacted with the most included the state park and FRIA, two branches of the Russian Orthodox Church, the Kodiak Area Native Association (KANA), the Kashia Pomo, and the California Department of Parks and Recreation.

The goals and desires of stakeholders are often different from the archaeologists' goals. In particular, archaeologists are trained to develop theoretically informed research questions that are 
testable. Most stakeholders are not necessarily concerned about broader theoretical issues. As Brown (2016: 135) notes from his experience excavating a World War I cemetery: 'They (the burials) retain an agency ... and have a presence, both physical in the cemetery and through their artefacts in a museum. They inspire and inform discussion, description, and remembrance.'

When the project began, the precise location of the cemetery was unclear, particularly in terms of the number of graves and extent of the site. This lack of knowledge was of great concern to the California Department of Parks and Recreation - how could they effectively protect and preserve a cemetery whose location and extent were unknown? The main cemetery was known to be located across from the fort, in view of the chapel, as directed by Russian Orthodox Church canon (Figure 3). However, this location does not account for all burials, since two individuals were accidentally recovered north and west of the cemetery. Both of these individuals appear to be isolated burials, one perhaps interred early in the life of the colony (Schulz 1972), and the other later in the fort's history (Sandra Hollimon, pers. comm. 2010). We do not know of any cultural reasons (e.g., crimes, suicide) that might account for these burials outside the cemetery. This is not to say that Russian Orthodox do not bury some people outside the cemetery boundaries, but in these instances, time - before the cemetery was founded and after the Russians left - appears to be the most likely explanation.

In general, the Russians who came to Ross belonged to the Russian Orthodox Church, and the Church presence was a strong one in this setting. The Russians had converted the native Alaskans who accompanied them, although their relationship with native Californians is less clear. We began by assuming that since the Russians established the cemetery, people followed traditional Russian Orthodox canon, with a distinct cemetery within view of the chapel, separated from the village, and including individual graves and traditional treatment. In the Russian settlements in Alaska of about the same time period and earlier, there were separate formal cemeteries following these customs, and there was every reason to believe that the same would be true for Fort Ross (Osborn 1997). 


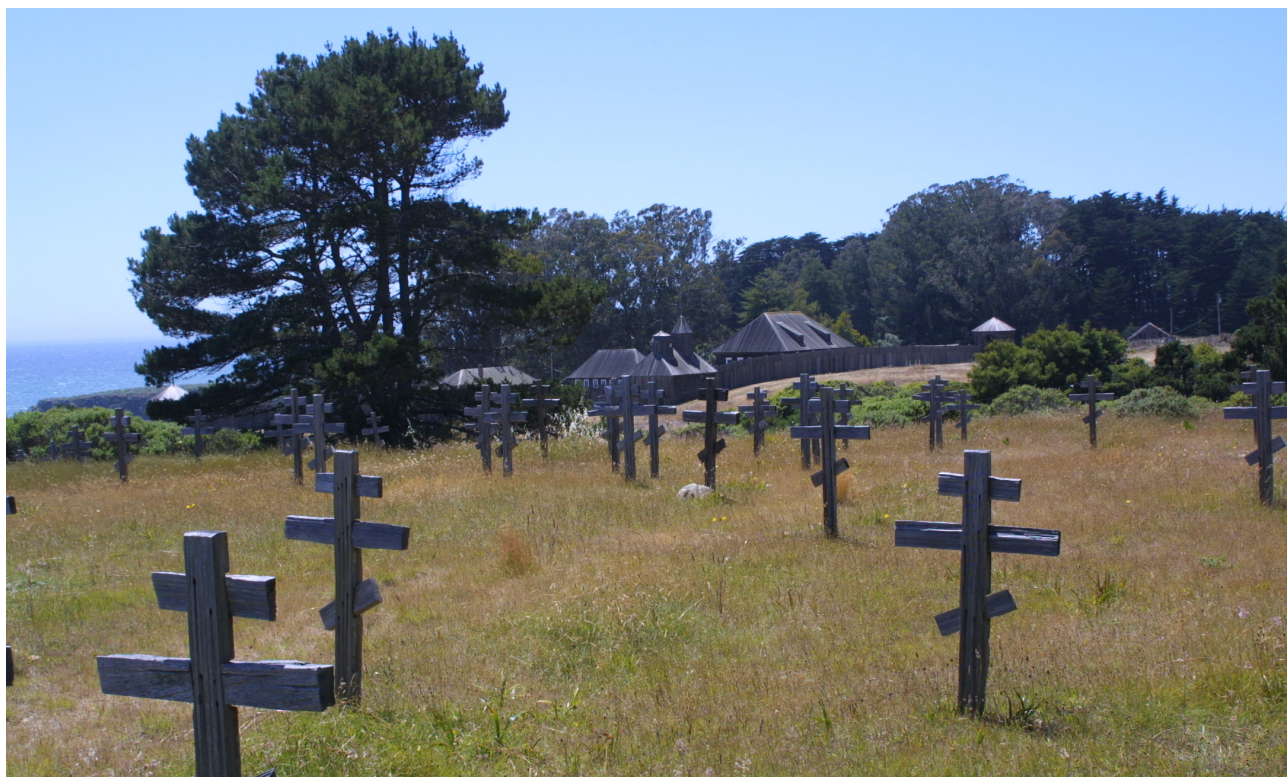

Figure 3: The cemetery's location in relation to the chapel (chapel in background is building closest to cemetery in foreground). Picture is looking west from the cemetery; the ocean is to the south.

\section{Excavation results}

We recovered a total of 131 graves with evidence of burials, and an additional four 'empty' graves. The empty graves may have been those in which preservation was exceptionally poor, or these features may represent graves from which individuals were later exhumed and their remains moved to other locations. Russian priests have noted that everyone was buried in the cemetery because both the Alaska Natives and the Kashia converted to Orthodox. Lightfoot et al. (1998) and others (Osborn 1997) have demonstrated that this was not necessarily true: Russians may have thought they converted them, but the Kashia thought otherwise. Kashia elders have stated that, according to oral tradition, their ancestors moved a number of buried Kashia back to their homes after the Russians left. Kashia tradition requires cremation, and the Kashia say that they never wanted their dead to be inhumed in the cemetery. One reason that some Kashia elders were interested in the cemetery excavation was that they wanted to see if there was evidence of Kashia individuals being removed (Otis Parrish, pers. comm. 1990). 
The Kashia asked that we not excavate any Kashia burials. We explained that we would keep that promise to the extent possible, but it was very likely that we would not know it was a Kashia grave until after it was excavated. Once that was known, we would cease excavation and/or immediately rebury the individual. They agreed to this procedure, but, as discussed in more detail below, none of the graves excavated could be identified as Kashia. Kashia elders regularly visited the excavations.

When we began the cemetery excavations, it became clear that heavy equipment would be needed to open the area for excavation; the soils were very dense and difficult to dig, and it would be impossible to clear sufficient area by hand. The park arranged for the equipment, and the main operator of that equipment was the late Warren Parrish, a local Kashia elder and son of Essie Parrish, a Kashia spiritual leader and expert basketmaker who had worked with anthropologists in the past. Warren was at the site nearly every day, providing insight and his interpretations of what we recovered. Figure 4 shows the excavations after clearing off about the top 50-60 cm.

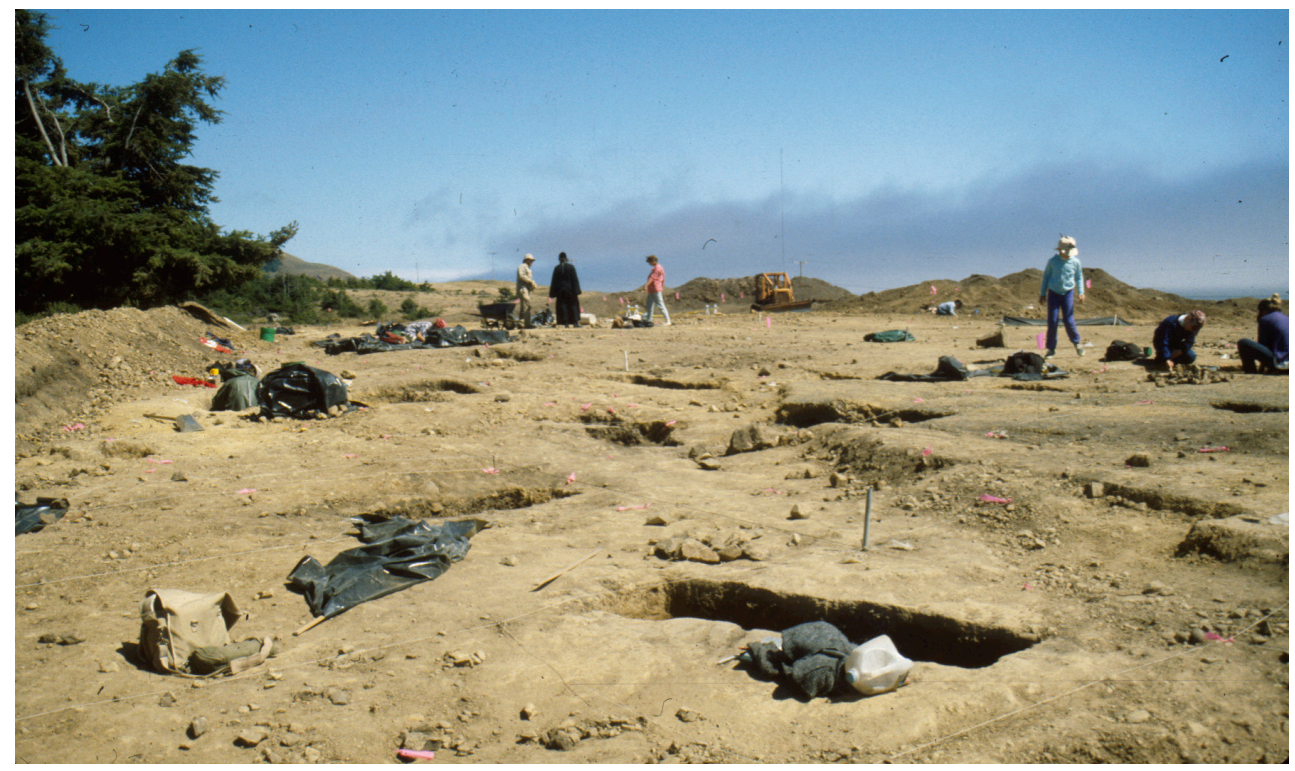

Figure 4: Excavations after machine clearing of the area. Note excavated graves. In the U.S., publication of burial photos is discouraged. 
The spatial pattern of the cemetery was generally in rows, following the topography (Figure 5), with people likely interred in order of death; that is, there is no evidence that the structure of the site is by status or rank or even by family, based on the nature of the individual graves. We expected some differentiation by rank, particularly given the clear social hierarchy that the Russians employed, yet such a pattern did not emerge. The earliest description of the cemetery is by Spanish priest Father Mariano Payeras who visited Fort Ross in the fall of 1822, and he notes several distinctions among the graves (Osborn 1997: 139-140). One of the features noted was a Three Saints Memorial, the likely location of which is indicated in Figure 5, where we found wooden remnants of a memorial. This Orthodox memorial may have been placed for higher status individuals or to mark the cemetery generally, but would not have necessarily been placed for a single individual. The memorial was visible until the 1907 earthquake, after which it collapsed.

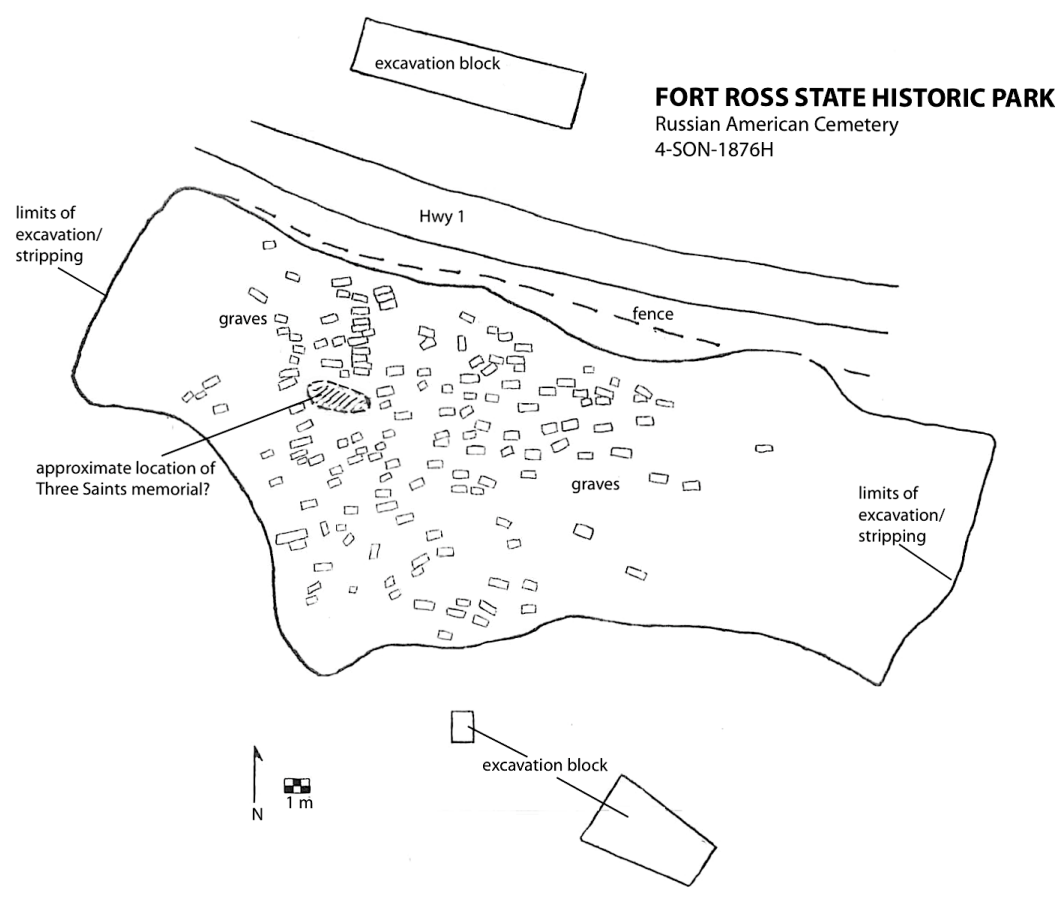

Figure 5: Map of the cemetery excavations, including graves excavated and all areas examined. The land slopes from north to south. 
The orientation of the graves in the cemetery was generally west-east (i.e. with the head to the west), so that at Resurrection the individual would sit up facing east, as dictated by Russian Orthodox canon (Father Alexander Krassovsky, pers. comm. 1990). Interestingly, at this point on the California coast, the Pacific Ocean is actually to the south rather than the west, and although some early burials apparently were placed with the assumption that the ocean was generally west, the location and orientation of later burials seem to have been adjusted for the proper orientation. Since a later commander of the fort was a seaman, he may have used his skills to correct the earlier error, or at least insure that the placement was accurate while he was in charge (Goldstein and Brinkmann 2006).

Coffins were narrow and made of redwood, and most burials seem to have had a coffin. If a coffin was absent, there was evidence of a cloth shroud. The coffins were constructed crudely, with butt-end joints, many nails, and rarely evidence of decoration or lining. Construction suggests that the coffins were made on site and expediently. We found a cross, or a religious medallion, in a total of $56 \%$ of graves (Figure 6 ), and other crosses or medallions may have been made out of wood or other perishable material.

Other grave-goods were present, but limited (Figure 7), and included such items as glass and metal buttons, glass beads, earrings, buckles, one military coat, bottles, some dishes, cloth, and a coin (see Goldstein and Brinkmann 2006). We had hoped that the beads might allow us to distinguish between Alaska natives and California natives since the groups favoured different kinds and colours of beads. Lester Ross (pers. comm. 1992) analyzed the beads and found that most were imported from Europe and are within the range of those used by Alaskan natives (Figure 7). None are specifically California native in style, colour choice, or pattern. We found two pairs of beaded earrings laid out in a distinct pattern, as well as evidence of several other beaded garments or items in place.

Bone preservation was poor due to high acidity in the soils, and in some areas, an anthropogenic pan formed within graves (Goldstein and Brinkmann 2006). The combination of physical and chemical processes made long-term preservation of the landscape unlikely; 
if we had not excavated the cemetery, it is unlikely that much would be left in another hundred years. The overall preservation at the cemetery was unusual; bone preservation varied from poor to absent, but occasionally items such as cloth were preserved. In addition to the soils, the redwood coffins tend to be acid in nature and likely contributed to the poor preservation. If a coffin was absent, there was slightly better, but not good, bone preservation.

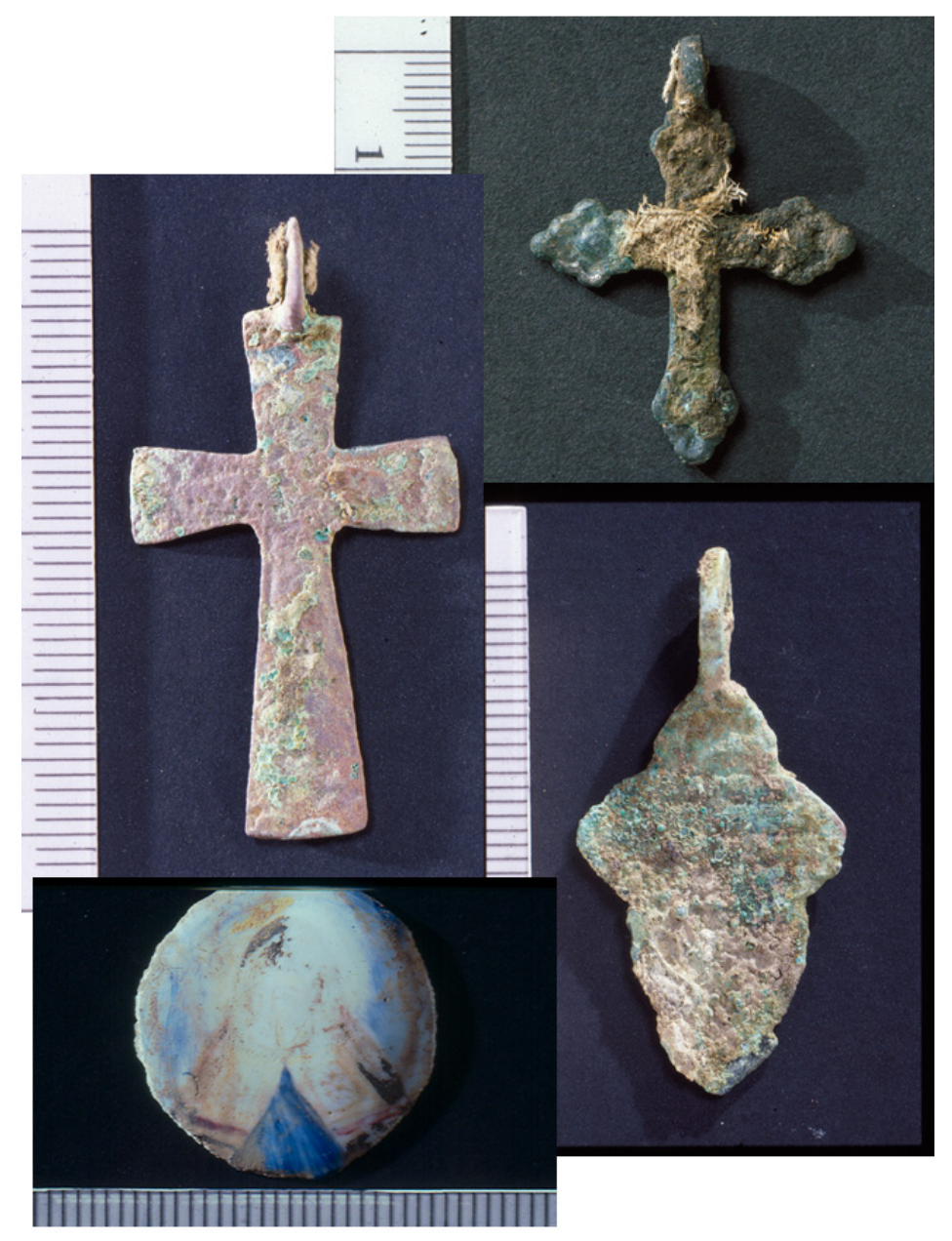

Figure 6: Religious items recovered from graves at the Fort Ross cemetery. Upper-left and upper-right are cross pendants; lower-right is religious medallion; lower-left is enameled pendant of St. Mitrophan, according to Russian Orthodox Archbishop. 


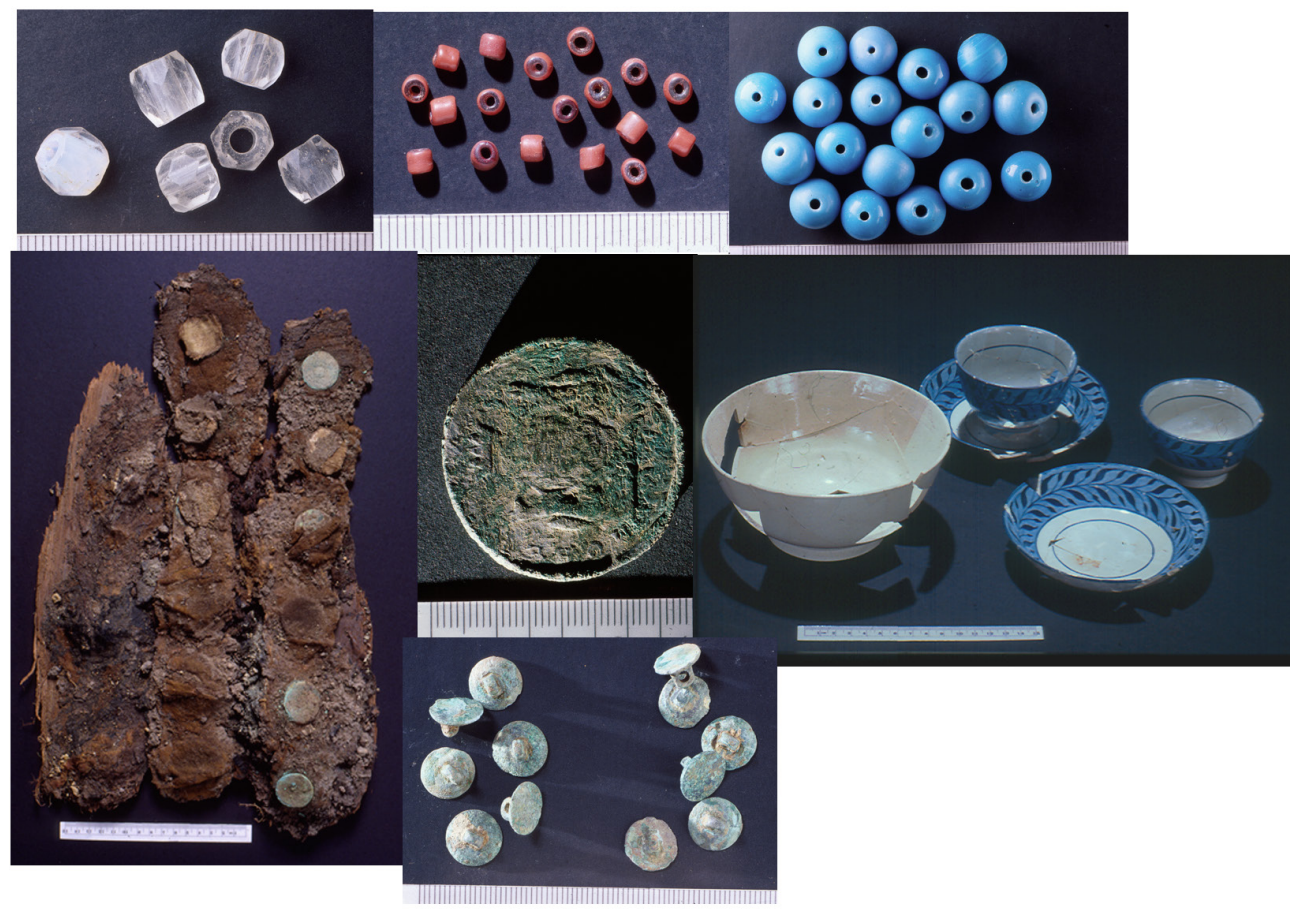

Figure 7: Other grave-goods recovered from the Fort Ross cemetery excavations (scales in metric). Top row - examples of beads; lower-left - remnant of military coat; centre is a 5 kopek piece; middle-right are examples of Spode china from one grave; lower-right are metal buttons.

\section{Modern impacts on the past}

As noted earlier, in the 1970s, one branch of the Russian Orthodox Church erected a large Russian Orthodox cross on the presumed cemetery site. When cemetery excavations began, the cross had to be moved because it was located within the presumed cemetery area. The California Department of Parks and Recreation and the Church approved moving the cross, and we discovered that the Church had placed the cross through the centre of an historic grave. The local priests were pragmatic and not concerned about this disturbance: their intentions had been good, and it was the overall cemetery visibility and commemoration that mattered. 
Part of our agreement with the California Department of Parks and Recreation, native groups, and the Russian Orthodox Church was that all individuals would be reburied in the graves from which they were excavated. The Church wanted everyone reburied in their original graves, but were not concerned about artefacts - if we could learn something from the artefacts, they should be kept and curated. Members of both branches of the Russian Orthodox Church, the Kashia Pomo tribe, and the Kodiak Area Native Association were kept apprised of all developments during excavation and analysis. Moreover, they were invited to visit and/or be present during all excavations, were encouraged to comment and inform, and were invited to a total of six separate reburial ceremonies overseen by priests from the Church. We held two reburial ceremonies each year, one for each branch of the Church. There was no way to identify individuals by name, so for each ceremony, we geographically and evenly divided the burials, one group for each church to rebury. Figure 8 represents how the cemetery looks today; each individual was reburied in their original grave, and a simple Russian Orthodox cross marks the foot of each grave.

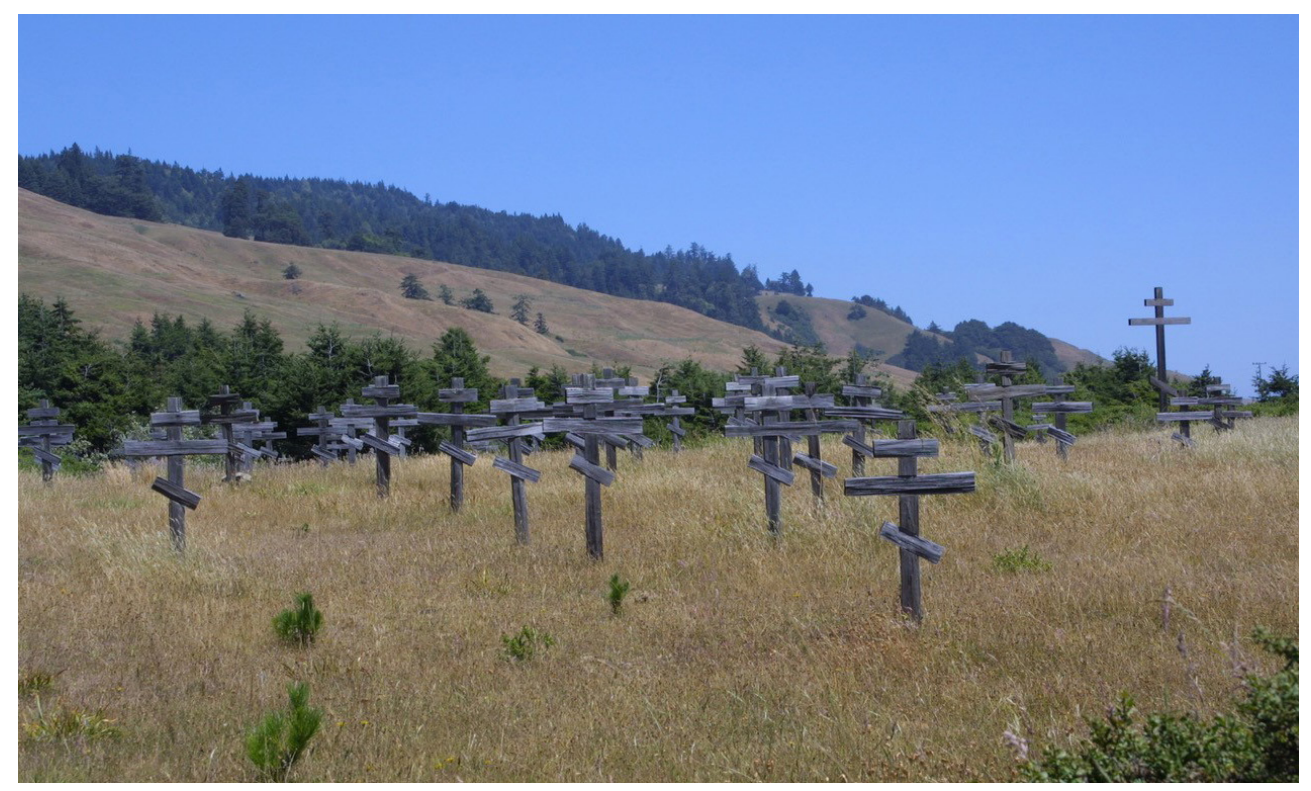

Figure 8: The historic Fort Ross cemetery today (looking southeast). Note the large cross that marks the site and was moved from its original location within the cemetery. 
The use of the simple Russian Orthodox crosses on each grave may have inadvertently imposed a coherence on the cemetery that may have been absent in the past. The Church was insistent that each burial be marked, and although we knew that there were some larger wood monuments at the high point of the cemetery, we did not know how many were present, and whether those marked the cemetery itself, a group of graves, or an individual grave. It was not surprising that we found no evidence of individual grave markers, since, if present, they would likely be relatively small, made of wood and subject to decay. While some wanted the monuments at the high point of the cemetery reconstructed, the more immediate problem was how to mark each grave. After much discussion among stakeholders and scholars, simple wooden Orthodox crosses for each grave seemed to be the best approach and was based on what was done at Orthodox cemeteries in Alaska of the same time period.

One of the priests with whom we collaborated, Father Alexander Krassovsky, worked diligently to bring the different branches of the church together, focusing on joint interests in Fort Ross. This was an extremely difficult and delicate undertaking because, historically, there had been little communication between the groups. One group held services annually at the cemetery site in late May, on Memorial Day, and the other group held services on 4 July. Each group requested their own reburial ceremonies, and although the project divided the burials into two groups for each set of reburial ceremonies, the priests made sure to include all burials in their services.

In 2012, Fort Ross celebrated the two hundredth anniversary of its founding, and Father Krassovsky worked for several years to coordinate a cemetery rededication and reconsecration by all branches of the Russian Orthodox Church (Figure 9). He was successful because of the symbolic importance of Fort Ross to all groups, and because they were pleased that the cemetery had been reconstructed and was clearly visible on the landscape as a cemetery. This event is one of the most significant direct results of the cemetery project.

Not surprisingly, the cemetery represents different things to each stakeholder group, and each group has a unique perspective 
on the importance of the site. The adaptations and decisions made over time tell us about the more human aspects of life on this harsh frontier and how perspectives change over time; they highlight, rather than detract, from the site's significance.

A few modern residents of the area had mixed feelings about our cemetery excavations. They understood that we had all of the required permissions, but they did not accept that cemetery excavation was desirable, necessary, or acceptable. The California burial law and procedures had been in placed for many years, and it was generally understood that cemetery excavations should be done only when threatened by construction. We maintained relationships with group members and kept them informed about the project. Some members of this group participate each summer in the Fort Ross Festival during which they don period costumes and celebrate the Fort. Although disapproving of the cemetery excavations, they appreciated the details on Russian period clothing construction that we were able to provide directly from the excavations.

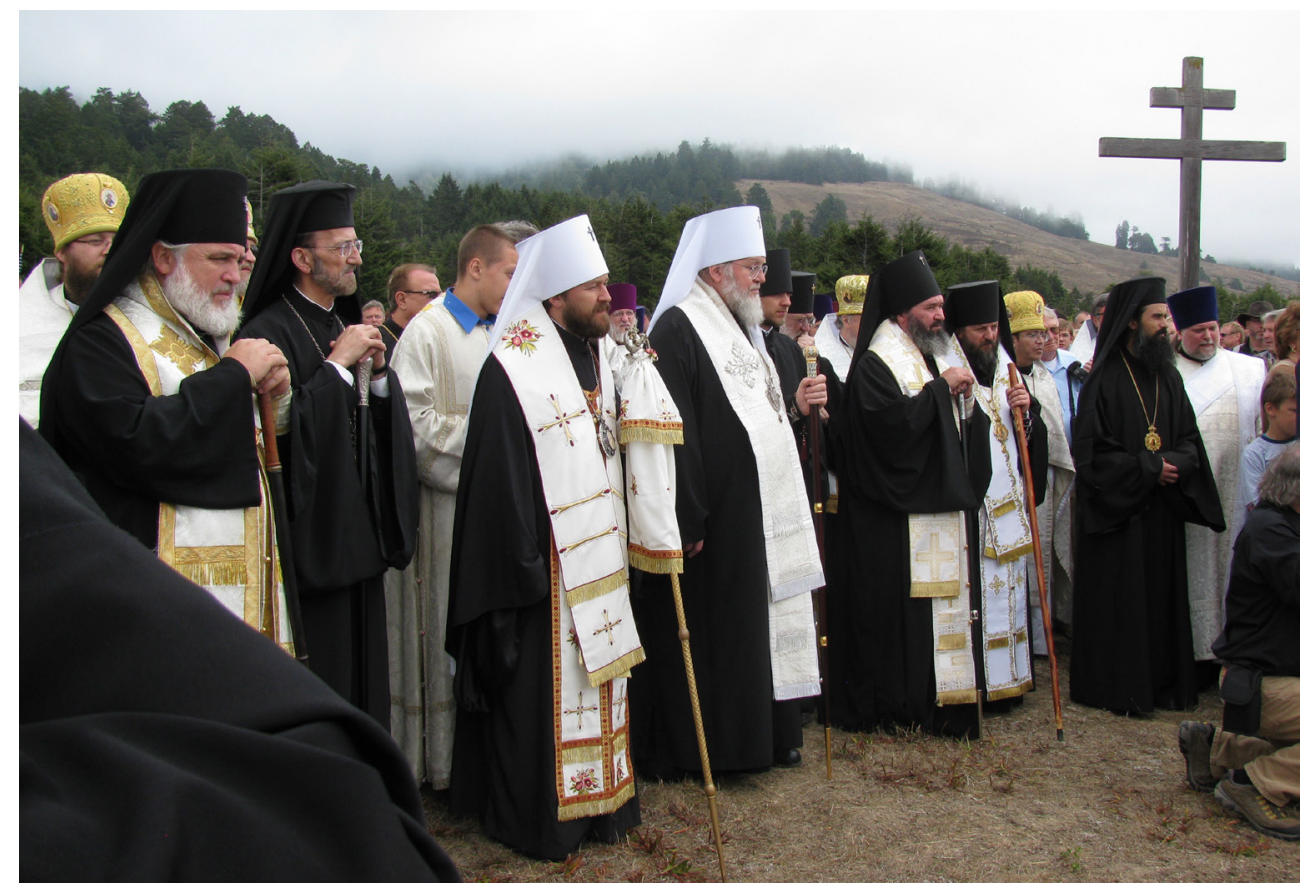

Figure 9: Rededication of the Fort Ross cemetery in 2012 by all groups of the Russian Orthodox Church. 
Very recently, after a visit to Fort Ross by the Russian ambassador to the U.S. in 2017, the Russian government has taken an interest in the cemetery because the ambassador felt that the cemetery was in poor condition (Alexander Zimin email comm., February 2018). According to the Russians, in 2016, the Washington office of the Russian side of the U.S.-Russia Joint Commission on Prisoners of War and Missing in Action (USJC on POW/MIAs) discovered that in 1812-1841, a number of sailors of the Russian Emperor's Navy died and were buried at Ross. Some archival research questions the validity of this statement (Glenn Farris, pers. comm., Feb. 2018), but the Russian government, working with Russian businesses, want to improve the appearance of the cemetery. As a first step toward undertaking this improvement, the Russian Federation officially recognized the cemetery as a Russian military burial site abroad.

The Russian plan includes the installation of new wooden Orthodox crosses on the graves and a large adoration cross with a stone slab at its foundation with the names of the buried (Alexander Zimin, email comm., 2 February, 2018). The Russian initiative has already received the support of Governor Brown of California, as well as the U.S. Secretary of Defense, James Mattis. The Russian government has also officially informed the State Department about the project. The work is being done in collaboration with the California Department of Parks and Recreation, the Kashia Pomo Tribal Government, the Fort Ross Conservancy, the Russian Orthodox Community of West America, as well as the Office of the Governor of Alaska. Finally, the Russian government wants to work closely with the archaeological community on this restoration. To this end, the cemetery was a focus of discussion at the 2018 Fort Ross Dialogue in Veliky Novgorod, Russia, and California State Parks is overseeing a project that includes ground-penetrating radar to determine if the cemetery extends beyond the areas examined as part of the original cemetery project. I was invited to attend the Veliky Novgorod conference (funded by several large multi-national companies including Transneft and Chevron), and presented an overview of the findings of the cemetery excavations. Notably, several of the business representatives at the conference commented that the report on the cemetery excavations made the Russian presence in California come alive in a way that had not been the case previously. 


\section{Ongoing cemetery interactions}

The Fort Ross cemetery project began in 1988, with a question about whether or not it would be possible to locate, excavate, and analyze the historic cemetery. In creating and designing a project that has had so much input and collaboration from stakeholders, one unanticipated result is that the project is never finished. As the cemetery draws new interest and becomes important to different groups in different ways, the archaeologist is drawn back into new plans and directions. This is not necessarily a negative, but as archaeologists conduct more collaborative work, it is important to remember that such projects can rarely be considered complete. Importantly, perceptions, uses, and interpretations of the project change over time, including some changes in stakeholders.

Brown (2016: 135) notes in his discussion of a First World War cemetery excavation: 'The process of excavation brings the individual back into the foreground of consciousness for different groups, whose reactions can and will simultaneously conflict, contrast, and yet share common ground in elements of remembrance.'

Cemeteries also draw the attention of people who are not necessarily stakeholders, but who are fascinated by the idea of a particular cemetery. This is well documented in several of the papers in Williams and Giles (2016), and has been a long-term issue for archaeologists, which we have not necessarily addressed very well. At Fort Ross, a nineteenth-century novelist typifies this kind of interest.

Although largely forgotten today, Gertrude Atherton was a San Francisco-based writer popular in the late 1800s. She made Fort Ross one focus for her literary work, and visited there on multiple occasions, staying in a hotel not too far away. She bribed some boys at the hotel to go with her to the cemetery and excavate one of the graves.

A redwood coffin was found in good preservation, except that the lid had fallen in and the interior was filled with earth. Search in this fill showed the 'shin bones,' the soles of the shoes, and some buttons, all that remained to indicate that there had been an occupant. Mrs. Atherton was much disgusted; she 
needed a dead Russian for literary purposes, and had hoped at least to get an officer with his trappings, if not indeed records buried with him. (Greene 1893: 14)

Atherton may have set her hopes a bit high, and the 1990s excavations may have located this grave; at the south edge of the cemetery, we found a clearly disturbed and expanded grave that had been excavated more than once. Although this grave may not be the one that Atherton and her party disturbed, it was disturbed in the historic past and still included a few bone fragments, some buttons and a religious medal.

Atherton wrote an entirely fictional and very dramatic love story about Fort Ross, with the heroine accidentally dying as she meets her love after a long period apart. The story (Atherton 1984) ends as follows:

They made her a coffin out of the copper plates used for their ships, and laid her in the straggling unpopulous cemetery on the knoll across the gulch beyond the chapel.

'When we go, we will take her,' said Rotscheff to his distracted wife.

But when they went, a year or two after, in the hurry of departure they forgot her until too late. They promised to return. But they never came, and she sleeps there still, on the lonely knoll between the sunless forest and the desolate ocean.

\section{Conclusions}

Returning to the stakeholders, all identified stakeholder groups were included and encouraged to collaborate, although not all groups chose to be involved. The project conducted a significant amount of outreach to the general public throughout the excavations, including welcoming all visitors to the site, undertaking public lectures, and newspaper and television coverage. Looking at the different stakeholders, we can examine whether or not they achieved their individual goals. 
1) Fort Ross State Historic Park and the Fort Ross Interpretive Association. The park wanted to make certain that the cemetery was identified, that it was treated with respect, and that new information be gained. The excavations resulted in a considerable amount of information that has been subsequently incorporated into the overall site's interpretation. Individual park rangers, interpreters, and maintenance people assisted the crew on a regular basis with a variety of tasks and problems. In 2012, the park hosted the bicentennial celebration of the founding of Fort Ross. The celebration drew many visitors, and included a rededication of the cemetery, with three new interpretive panels.

2) The Russian Orthodox Church. Both branches of the Church remained actively interested and involved in the project from the very beginning. A variety of church representatives visited the excavations regularly, and provided extensive information on burials customs and Russian Orthodox canon, as well as interpretation of religious symbols. The primary focus of the Church's interest was in making the cemetery visible as a cemetery; they wanted each grave marked, and the cemetery as a whole set aside as consecrated ground. More recently, one of the priests used the cemetery and the Fort's bicentennial celebration as a means to bring the different branches of the church together. By focusing on the cemetery rededication, differences could be minimized and the Russian past and common interests celebrated.

3) Kodiak (Alaska) Area Native Association. Senior State Park Archaeologist E. Breck Parkman visited Kodiak to request permission for the project. He discussed the project in detail with the association and with representatives of the Russian Orthodox Church in Alaska. Because the cemetery was created and organized by the Russians at Fort Ross, the native group decided to let a local Russian Orthodox priest be the point-of-contact person for their interests. They made no specific requests, beyond wanting the cemetery to be visible and maintained as a cemetery. We sent them regular reports of the excavations and included them in all communications.

4) Kashia Pomo. The Kashia visited regularly, and one Kashia elder served as the project's heavy machinery operator. Many Kashia had been told that no Kashia would be found in the cemetery 
because they would have been moved after the Russians left, and they wanted this information verified. We could not directly prove that this was the case, but we did not find any graves that could be specifically identified as Kashia, and we found four graves that had been deliberately excavated, but contained no evidence of a burial. Several elders told us that a few Russian children had drowned and that the Kashia had returned their bodies to the fort. Although there were children buried in the cemetery, we could not verify this specific story.

5) California Department of Parks and Recreation. The California Department of Parks and Recreation issued the required permits, and a number of people in the department are scholars of the time period and have considerable knowledge about Fort Ross. They were extremely helpful throughout all stages of this project, and continue to be helpful and inclusive. Their main concern at the time of excavation was identifying the cemetery location, and clarifying the nature of the cemetery, so that they could maintain and preserve it. All artefacts that were not reburied are housed in the department. The department was able to use the project for publicity, and they continue to include Goldstein in discussions and interpretations about the cemetery.

We did not originally include the Russian government as a separate entity in our initial identification of stakeholders, in part because of the politics of the time. We discussed our plans and details of the excavations with scholars and museums in Russia, as well as Orthodox Church officials, and they have all remained interested. However, in 1989, Russian government officials did not see the project as something of interest to those outside the museum and religious world. It is possible that we should have pushed this with the Russian government more than we did, but we simply accepted their lack of interest. Recently, however, as the Russian government has become more involved in the operation of Fort Ross (the private Renova Fort Ross Foundation is a Russian business conglomerate that created a foundation to provide funds to Fort Ross for specific projects), they have become more interested in all Fort Ross research. They approve of the cemetery excavations, but now want the site treated as an official Russian 
military cemetery, and want to fund cemetery restoration. As noted earlier, the Russian government has already designated the site as a military cemetery, and there is nothing that anyone in the United States can do about that. However, negotiating precisely what a restoration will entail will be the focus of future discussions, and will include archaeologists, as well as state government, federal government, and state park officials.

The Fort Ross cemetery represented and continues to represent different things to different people and groups at different times. As I noted in discussing the papers in Williams and Giles (2016): 'Material objects have a social life, but human remains have both a social life and power in the past, in the present, and in the past in the present' (Goldstein 2016: 450).

Comparing the work at Fort Ross to other cemetery excavation projects may make the Fort Ross case appear to be more successful, and there were relatively few major problems or disagreements. However, there are a variety of reasons that the Fort Ross excavations succeeded. First, we spent eighteen months negotiating permissions, working with stakeholders, and determining stakeholder interests. Second, the project began almost thirty years ago. There were fewer laws and procedures in place at the time, although California was ahead of most of the U.S. in its burial laws, and the laws were quite strict. Stakeholders were certainly vocal at the time, but likely not as sophisticated as they are today. By contrast, today's stakeholders have laws to support their involvement, have experience working with archaeological projects, and understand what kinds of information archaeology is able to provide. In this project, we attempted to include all possible stakeholders, and we were as collaborative as possible. One of the most significant things we did was to identify what result or 'product' each stakeholder group wanted from the cemetery excavations, whether that was confirmation that they were not present, identification of cemetery boundaries or a specific event, or recognition of the site. Unlike most cemetery excavations, there was no construction or other direct threat to the site, so it was critical to get a different kind of approval. People were not giving approval to get information before a site was destroyed. In this case, groups needed to determine that there was information that the excavations might provide, 
and that was not otherwise available. As Smith (2006: 3) notes in her discussion of heritage as a cultural process, heritage 'is used to construct, reconstruct, and negotiate a range of identities and social and cultural values and meanings in the present.' The Fort Ross cemetery excavations represent, in Smith's (2006) terms, a multi-layered performance that negotiates and constructs a sense of place in the present. The cemetery is used to present both an agreed version of the past, as well as a contested one.

Finally, it is important to reiterate that unlike some other projects, this project is never finished, and the archaeologist is drawn into discussions and debates again and again over the decades following the fieldwork. This may well be true of excavations in any cemetery that remains accessible and interpreted. The Fort Ross cemetery is now a clear, visible, and important physical presence in the park. As people interact with the site, different questions, concerns, and interpretations arise, but the detail of the excavations are not readily available to all. As Smith (2006:2) also notes, the idea of heritage is not so much a 'thing', but a social and cultural process that 'engages with acts of remembering that work to create ways to understand and engage with the present.' People learn some things from reading interpretive signs, but they learn more from stories, rituals, celebrations, and interactions provided by tour guides, relatives, friends, and other stakeholders. From this perspective, ongoing archaeological involvement in a cemetery project can prove to be a benefit to the archaeologist and the various publics.

\section{Acknowledgements}

I gratefully acknowledge the generosity and assistance of the California Department of Parks and Recreation, and especially E. Breck Parkman, Glenn Farris, and the rangers and other park employees who worked at Fort Ross during the research period (Dan Murley, Bill Walton, and Bill Mennell went above and beyond the call of duty to assist and make our work easier). In addition, I want to thank the University of Wisconsin-Milwaukee (where I worked at the time) field school students and other volunteers who helped excavate and analyze the Fort Ross materials. I am very grateful to the Kashia Pomo, Kodiak Island people, and officials of the Russian 
Orthodox Church from Alaska and California who collaborated with us, providing advice, encouragement, information, and history. I am also grateful to the late Warren Parrish, Kashia Pomo and state park employee, who helped us throughout our excavations and operated the heavy equipment that made the excavations possible.

\section{References}

Atherton, G. 1894. Natalie Ivanhoff: a memory of Fort Ross. In Before the Gringo Came. New York, J. Selwin Tait \& Sons.

Blomkvist, E. E. 1972. A Russian scientific expedition to California and Alaska, 1839-1849. Oregon Historical Quarterly, June 1972, 101-170.

Brown, M. 2016. Habeas corpus: contested ownership of casualties of the Great War. In H. Williams and M. Giles (eds), Archaeologists and the Dead: Mortuary Archaeology in Contemporary Society, Oxford, Oxford University Press, 113-138.

Clegg, M., Redfern, R., Bekvalac, J., and Bopnney, H. 2013. Conclusions. In M. Clegg, R. Redfern, J. Bekvalac and H. Bonney (eds), Global Ancestors: Understanding the Shared Humanity of Our Ancestors. Oxford, Oxbow Books, 162-63.

Clegg, M., Redfern, R., Bekvalac, J. and Bonney, H. (eds) 2013. Global Ancestors: Understanding the Shared Humanity of Our Ancestors. Oxford, Oxbow Books.

Farris, G. J. 1992. Life at Fort Ross as the Indians Saw It: Stories from the Kashaya. Paper in the collections of the Fort Ross Conservancy Library, Fort Ross State Park.

Federova, S. G. 1973. The Russian Population in Alaska and California, Late $18^{\text {th }}$ Century-1867. Translated and edited by Richard A. Pierce and Alton S. Donnelly. Materials for the Study of Alaska History, No. 4. Kingston, Ontario, The Limestone Press.

Federova, S. G. 1975. Ethnic Processes in Russian America. Translated by Antoinette Shalkop. Occasional Paper No. 1. Anchorage, Anchorage Historical and Fine Arts Museum. 
Fforde, C., Hubert, J. and Turnbull, P. (eds) 2002. The Dead and Their Possessions: Repatriation in Principle, Policy and Practice. One World Archaeology Series, no. 43. New York, Routledge.

Gibson, J. R. 1976. Imperial Russia in Frontier America: The Changing Geography of Supply of Russian America, 1784-1867. New York, Oxford University Press.

Giles, M. and Williams, H. 2016. Introduction: mortuary archaeology in contemporary society. In $\mathrm{H}$. Williams and $\mathrm{M}$. Giles (eds), Archaeologists and the Dead: Mortuary Archaeology in Contemporary Society. Oxford, Oxford University Press, 1-18.

Goldstein, L. 2016. Reflections on intersections of mortuary archaeology and contemporary society. In $\mathrm{H}$. Williams and $\mathrm{M}$. Giles (eds), Archaeologists and the Dead: Mortuary Archaeology in Contemporary Society. Oxford, Oxford University Press, 433-51.

Goldstein, L. and Brinkmann, R. 2006. The context of the cemetery at Fort Ross: multiple lines of evidence, multiple research questions. Pacific Coast Archaeological Society Quarterly 39(4), $1-21$.

Greene, C. S. 1893. Fort Ross and the Russians. The Overland Monthly 22(127), 1-15.

Harrison, R. 2013. Heritage: Critical Approaches. London and New York, Routledge.

Hasse, Y. D. 1952. The Russian-American Company in California. Unpublished MA Thesis, University of California, Berkeley.

Knecht, R. A. and Jordan, R. A. 1985. Nunakakhnak: an historic Koniag village in Karluk, Kodiak Island, Alaska. Arctic Anthropology 22(1), 1-35.

Lightfoot, K. G. 2005. Indians, Missionaries, and Merchants: The Legacy of Colonial Encounters on the California Frontiers. Berkeley, University of California Press.

Lightfoot, K. G., Martinez, A. and Schiff, A. M. 1998. Daily practice and material culture in pluralistic social settings: an archaeological study of culture change and persistence from Fort Ross, California. American Antiquity 63 (2), 199-222. 
Lowenthal, D. 1985. The Past Is a Foreign Country. Cambridge, Cambridge University Press.

Lowenthal, D. 2015. The Past Is a Foreign Country - Revisited. Cambridge, Cambridge University Press.

Osborn, Sannie. 1997. Death in the Daily Life of the Ross Colony: Mortuary Behavior in Frontier Russian America. Unpublished PhD Dissertation, Department of Anthropology, University of Wisconsin-Milwaukee.

Redfern, R. and M. Clegg. 2013. Introduction. In Clegg, M., Redfern, R., Bekvalac, J. and Bonney, H. (eds) Global Ancestors: Understanding the Shared Humanity of Our Ancestors. Oxford, Oxbow Books, 1-7.

Schulz, P. D. 1972. Osteological Analysis of an Historic Burial at Fort Ross, California. Unpublished manuscript, California Department of Parks and Recreation, Sacramento.

Skrede, J. and Hølleland, H. 2018. Uses of heritage and beyond: heritage studies viewed through the lens of critical discourse analysis and critical realism. Journal of Social Archaeology 18(1), 77-96.

Smith, L. 2006. Uses of Heritage. London and New York, Routledge,

Wikipedia. 2017. Russian Orthodox Church. https://en.m.wikipedia. org/wiki/Russian_Orthodox_Church (accessed on September 8, 2017).

Williams, H. and Giles, M. (eds) 2016. Archaeologists and the Dead: Mortuary Archaeology in Contemporary Society. Oxford, Oxford University Press

Zimin, A. 2018. Email to Lynne Goldstein. (Zimin is Deputy Head of Economic Affairs Office, Embassy of the Russian Federation to the U.S.). 